\title{
A One-Day Sensitive Method to Detect and Distinguish Between the Citrus Black Spot Pathogen Guignardia citricarpa and the Endophyte Guignardia mangiferae
}

\author{
L. Meyer, G. M. Sanders, R. Jacobs, and L. Korsten, Department of Microbiology and Plant Pathology, Forestry \\ and Agricultural Biotechnology Institute, University of Pretoria, Pretoria, 0002, South Africa
}

\begin{abstract}
Meyer, L., Sanders, G. M., Jacobs, R., and Korsten, L. 2006. A one-day sensitive method to detect and distinguish between the citrus black spot pathogen Guignardia citricarpa and the endophyte Guignardia mangiferae. Plant Dis. 90:97-101.

If South African citrus exporters wish to retain their competitive edge in the European market and access new markets such as the United States of America, it is of quarantine importance to distinguish between the citrus black spot pathogen, Guignardia citricarpa, and the harmless endophyte, G. mangiferae. The endophyte is not a sanitary or phytosanitary concern. This paper describes the design of species-specific primers that are able to detect and distinguish between these two Guignardia species. Application of the primer set CITRIC1 and CAMEL2 in conjunction with the ITS4 primer yielded polymerase chain reaction (PCR) amplicons of approximately $580 \mathrm{bp}$ and $430 \mathrm{bp}$ for G. citricarpa and G. mangiferae, respectively. Results obtained with these primers are in accordance with sequence data, and repeated tests verified accuracy and sensitivity. A BLAST search revealed no matches other than G. citricarpa and G. mangiferae, and no positive PCR results were obtained with Colletotrichum gloeosporioides, which is the most common contaminant in black spot lesions. We are, therefore, able to distinguish G. citricarpa and $G$. mangiferae unequivocally using a PCR-based method. This method was further improved to directly isolate DNA from fruit lesions by means of the DNeasy Plant Mini Kit (Qiagen). This eliminates the prior need for culturing the slow-growing organism, thereby shortening the time required to one day to test for and verify the presence or absence of the pathogenic G. citricarpa in export consignments.
\end{abstract}

Additional keywords: DNA extraction, Phyllosticta

Increased global trade in fresh fruit has resulted in setting minimum standards and harmonization of legislation dealing with import requirements and specifications. Lack of acceptance of test data for these specifications across national borders has been identified as a technical barrier to trade (8). The World Trade Organization has subsequently adopted two new agreements to ensure that technical requirements do not restrict trade viz. the agreement on Technical Barriers to Trade and the agreement on Sanitary and Phytosanitary measures (8). Despite this, restrictions on citrus consignments to the European Union (EU) and the United States of America (USA) threaten continued exports from South Africa $(2-4,13)$.

The fungus Guignardia citricarpa Kiely (anamorph Phyllosticta citricarpa (McAlp.) Van der Aa) causes citrus black spot (CBS), a disease subject to phytosanitary restrictions $(3,19,20,40)$. Preharvest CBS lesions resulting from field infections af-

Corresponding author: Linda Meyer

E-mail: lindam@postino.up.ac.za

Accepted for publication 16 August 2005.

DOI: 10.1094/PD-90-0097

(C) 2006 The American Phytopathological Society fect the appearance of the fruit and thus significantly reduce potential export revenue (19). In addition, latent infections that are not associated with symptoms at the time of harvesting can also develop on fruit in transit during export $(10,18,20)$.

For many years, a morphologically similar Guignardia sp. on citrus was often incorrectly identified as the citrus pathogen causing CBS $(17,26,40)$. Meyer et al. (28) proved the existence of two distinct species of Guignardia on citrus by means of sequence analysis of the internal transcribed spacer (ITS) regions of the rRNA operon. Baayen et al. (6) subsequently designated this harmless endophyte as Guignardia mangiferae A.J. Roy (anamorph Phyllosticta capitalensis P. Hennings). $G$. citricarpa causes CBS and $G$. mangiferae does not cause symptoms, although it has been isolated from symptomatic and asymptomatic citrus fruit rind and leaves $(6,28)$. G. mangiferae tends to grow faster in culture than the CBS pathogen. It may also produce perithecia, but in general, morphology is insufficient to distinguish these congeners of Guignardia $(26,27,37,38)$.

Timeliness and accuracy of pathogen identification are crucial and cultivation of the slow-growing G. citricarpa is undesirable in time-critical diagnosis of export consignments. Appropriate quarantine de- cisions, affecting exports, were previously only made after carefully studying cultures made from the suspect fruit. Since the differentiation between G. citricarpa and G. mangiferae was based on morphological features alone, the endophyte was often incorrectly identified as G. citricarpa. Isolation, culturing, and examination of isolates takes anything from 5 to 14 days, with an efficacy of less than $50 \%(4,5,14)$. In many instances, where exporters screen citrus consignments for pathogen-free validation, the fruit is kept at the harbor for extended periods of time. The value of the consignment decreases rapidly with each additional day spent in holding. The limitations of the cultivation of slow-growing microorganisms can be sidestepped with the culture-independent polymerase chain reaction (PCR) process, which has previously been applied successfully in various natural environments $(7,12,22,29,30,33,36)$.

A direct PCR test on fruit lesions was developed at the University of Oregon (US) and Plant Research International, Wageningen (NL) for the detection of $G$. citricarpa (9). Even though this method can be done in 2 days, a same-day test is still required for South African fruit exports, which are often rejected at the harbor due to the presence of a single fruit spot suspected of being CBS. In addition, Bonants et al. (9) did not provide any evidence of successfully amplifying $G$. mangiferae. The endophyte $G$. mangiferae can, however, be present in the peel prior to lesion formation by other pathogens, such as pathogenic Colletotrichum species, ever-present in the peel $(6,15)$. Minute spots on grapefruit, lemon, and lime fruits often produce cultures of $G$. mangiferae $(6,28)$. It is therefore necessary to accurately distinguish between the two Guignardia species in preference of identifying G. citricarpa alone.

The aim of this study was to develop a same-day test to unequivocally identify the citrus black spot pathogen and distinguish it from the omnipresent endophyte. This involved the isolation of DNA from fruit lesions and the design of a primer set based on ITS sequences, which would distinguish the two species of Guignardia.

\section{MATERIALS AND METHODS}

Fungal isolates. A set of 23 Guignardia isolates was selected for this study. These isolates were from the major citrusproducing areas in South Africa, from 
different cultivars (lemons, sweet oranges, grapefruit, tangerine [C. reticulata Blanco], and kumquat [Fortunella Swingle]), different lesion types, and alternative hosts, i.e., avocado (Persea americana Mill.), mango (Mangifera indica L.), banana (Musa acuminata Colla), and cabbage tree (Cussonia Thunb.) plants (Table 1). The fungal isolates were obtained by direct isolation from host tissue onto potato dextrose agar (PDA) (Biolab, Merck, South Africa) supplemented with $250 \mathrm{mg}$ of chloramphenicol (The Premier Pharmaceutical Co., SA). Fruit were surface-sterilized for 2 min using $1.5 \% \mathrm{NaOCl}$ and rinsed thoroughly. A thin layer of the fruit surface surrounding the lesion was removed using a scalpel, and the exposed tissue was cut into $2 \times 2 \mathrm{~mm}$ squares and plated onto PDA plates. An ex-holotype culture of the species, Phyllosticta citricarpa from the Centraalbureau of Schimmelcultures (CBS111.20), was used as a comparative standard in all tests. Isolate GC172 was used throughout this study as standard for the newly named $G$. mangiferae. DNA of these isolates was extracted, the ITS regions amplified, and sequencing reactions were carried out and data processed as described previously by Meyer et al. (28).

Plant material. Asymptomatic and symptomatic lemon (cv. Eureka), oranges (cv. Valencia, Midnight, and Navel), and grapefruit (cv. Marsh) with symptoms including typical and atypical hard spot lesions, false melanose, postharvest red spots, freckle spot, and virulent spot were collected from Sandvlei, Letaba, Karino, Nelspruit, Marble Hall, Hermitage, Croc Valley Estates, Westfalia, and Burgersfort (all in South Africa) as well as fruit from Sao Paolo (Brazil) and Chiredzi (Zimbabwe) (Table 2).
DNA extractions. DNA of all the isolates mentioned in Table 1 was extracted from freeze-dried mycelium using the technique described by Raeder and Broda (34). The DNeasy Plant Mini Kit (Qiagen, Valencia, CA) was evaluated for rapid production of sufficient DNA of a suitable quality for PCR from fruit lesions (different types and sizes), fungal cultures, and freeze-dried mycelium (Table 2). Fungal growth was removed from 10- to 14-dayold cultures on PDA up to $100 \mathrm{mg}$ wet weight. Freeze-dried fungal mycelium was ground to a powder, and 20 to $30 \mathrm{mg}$ was used per DNA extraction. Fruits were surface-disinfested with $70 \%$ (vol/vol) ethanol and left to air dry, and lesions were carefully dissected from fruits. Half of the lesion was plated on PDA and the other half was ground to a fine powder in liquid nitrogen, and extractions were performed using the DNeasy Plant Mini Kit according to the manufacturer's instructions. The elution volume was reduced to $1 \times 75 \mu$ l. Successful extractions were confirmed using a $1.0 \%(\mathrm{wt} / \mathrm{vol})$ agarose gel in TBE buffer (23).

Primer design and PCR conditions for detection of $G$. citricarpa and $G$. mangiferae. The design of oligonucleotide primers CITRIC1 (5'-GAA AGG TGA TGG AAG GGA G-3') and CAMEL2 (5'-AGT ATA CAA AAC TCA AGA ATT C- $3^{\prime}$ ) was based on the DNA sequences of previously sequenced ITS regions (28). For detection and differentiation of $G$. citricarpa and $G$. mangiferae, these two primers were used together with the ITS4 primer (42). The primers were synthesized by MWG Biotech (Germany). PCR reactions were performed in 50- $\mu$ l volumes, each reaction containing 1 $\mu \mathrm{l}$ of template DNA, primers, i.e., CITRIC1
(10 pmol), CAMEL2 (60 pmol), and ITS4 (15 pmol), $5 \mu$ l of recommended $10 \times$ buffer (supplied with $\mathrm{Taq}$ polymerase), $200 \mu \mathrm{M}$ of each dCTP, dGTP, dATP, and dTTP (Ta$\mathrm{KaRa}$ ), and 0.5 U Taq polymerase (Ta$\mathrm{KaRa}$ ). Following an initial denaturation step of $95^{\circ} \mathrm{C}$ for $2 \mathrm{~min}, 35 \mathrm{PCR}$ cycles were performed on a Perkin-Elmer 2400 thermocycler using the following conditions: a denaturation step of $93^{\circ} \mathrm{C}$ for $30 \mathrm{~s}$ followed by annealing at $56^{\circ} \mathrm{C}$ for $45 \mathrm{~s}$ and extension at $72^{\circ} \mathrm{C}$ for $90 \mathrm{~s}$, followed by a final extension of $72^{\circ} \mathrm{C}$ for $7 \mathrm{~min}$. The amplified DNA fragments were visualized on a $1.25 \%$ (wt/vol) agarose gel in TBE buffer (23). A purified DNA extract from an avocado isolate of Colletotrichum gloeosporioides (Penz.) Penz. \& Sacc. in Penz. and water were included as negative controls.

Evaluation of primer sets. In order to confirm the specificity of the primers, they were analyzed using the BLAST program (1) (National Centre for Biotechnology Information). Some of the previously sequenced isolates (28) were used to evaluate the efficacy of the primer sets (Table 1). Other isolates, including Guignardia isolates of unknown identity and direct DNA isolations from fruit, were included in the evaluation process (Table 2). All tests were repeated five times to ensure consistency of results. In some instances, DNA originating from the same lesion, either directly isolated from the fruit lesion or first cultured for 5 days on PDA, were used. PCR analysis was conducted on all these isolates as described previously.

\section{RESULTS}

Specificity of PCR amplification. Results of PCR analyses are shown in Table 2. PCR amplification using these primer

Table 1. Guignardia citricarpa and G. mangiferae isolates used for selection and validation of the CITRIC1 and CAMEL2 primers

\begin{tabular}{|c|c|c|c|c|c|}
\hline Species name & Isolate code & Origin $^{a}$ & Host cultivar & Lesion type & Accession no. ${ }^{b}$ \\
\hline G. citricarpa & $\begin{array}{l}\text { GC62 } \\
\text { GC63 } \\
\text { GC87 } \\
\text { GC25 } \\
\text { GC31 } \\
\text { GC154 } \\
\text { GC149 } \\
\text { GC4 } \\
\text { GC51 } \\
\text { GC66 } \\
\text { GC80 } \\
\text { GC45 } \\
\text { CBS111.20 }\end{array}$ & $\begin{array}{l}\text { Letsitele, MP } \\
\text { Letsitele, MP } \\
\text { Nelspruit, MP } \\
\text { Hoedspruit, MP } \\
\text { Swaziland } \\
\text { Nkwaleni, KZN } \\
\text { Malelane, MP } \\
\text { Zebediela, MP } \\
\text { Croc Valley, MP } \\
\text { Karino, MP } \\
\text { Croc Valley, MP } \\
\text { Alkmaar, MP } \\
\text { NSW, Australia }\end{array}$ & $\begin{array}{l}\text { Citrus sinensis cv. Valencia } \\
\text { C. sinensis } \mathrm{cv} \text {. Valencia } \\
\text { C. sinensis } \mathrm{cv} \text {. Valencia } \\
\text { C. sinensis } \mathrm{cv} \text {. Valencia } \\
\text { C. paradisi cv. Marsh } \\
\text { C. paradisi cv. Marsh } \\
\text { C. paradisi cv. Star Ruby } \\
\text { C. limon } \mathrm{cv} \text {. Eureka } \\
\text { C. limon cv. Eureka } \\
\text { C. limon cv. Eureka } \\
\text { C. limon cv. Eureka } \\
\text { C. reticulata cv. Nova } \\
\text { Citrus } \mathrm{sp} \text {. Ex holotype }\end{array}$ & $\begin{array}{l}\text { Red margin } \\
\text { Freckled spot } \\
\text { False melanose } \\
\text { Hard spot } \\
\text { Hard spot } \\
\text { Red margin } \\
\text { Hard spot } \\
\text { Hard spot } \\
\text { Virulent spot } \\
\text { Hard spot } \\
\text { Hard spot } \\
\text { Hard spot } \\
\text {... }\end{array}$ & $\begin{array}{l}\text { AF346779 } \\
\text { AF346780 } \\
\text { AF374371 } \\
\text { AF374365 } \\
\text { AF374366 } \\
\text { AF346775 } \\
\text { AF346774 } \\
\text { AF346778 } \\
\text { AF346773 } \\
\text { AF374367 } \\
\text { AF374370 } \\
\text { AF346776 } \\
\text { AF346772 }\end{array}$ \\
\hline G. mangiferae & $\begin{array}{l}\text { GC117 } \\
\text { GC119 } \\
\text { GC146 } \\
\text { GC41 } \\
\text { GC10 } \\
\text { GC6 } \\
\text { GC172 } \\
\text { GC5 } \\
\text { GC14 } \\
\text { GC18 }\end{array}$ & $\begin{array}{l}\text { Nkwaleni, KZN } \\
\text { Nkwaleni, KZN } \\
\text { Malelane, MP } \\
\text { Patensie, Scape } \\
\text { Letaba, MP } \\
\text { Pretoria, GP } \\
\text { Letaba, MP } \\
\text { Nelspruit, MP } \\
\text { Port Edward, KZN } \\
\text { Letaba, MP }\end{array}$ & $\begin{array}{l}\text { C. paradisi } \mathrm{cv} \text {. Marsh } \\
\text { C. paradisi } \mathrm{cv} \text {. Marsh } \\
\text { C. paradisi } \mathrm{cv} \text {. Star Ruby } \\
\text { C. limon } \mathrm{cv} \text {. Eureka } \\
\text { Fortunella } \mathrm{sp} . \\
\text { Cussonia } \mathrm{sp} \text {. } \\
\text { Mangifera indica } \\
\text { Musa acumunata } \\
\text { M. acumunata } \\
\text { Persea americana }\end{array}$ & $\begin{array}{l}\text { No visible symptoms } \\
\text { Red margin } \\
\text { No visible symptoms } \\
\text { No visible symptoms } \\
\text { No visible symptoms } \\
\ldots \\
\ldots \\
\ldots \\
\ldots \\
\ldots\end{array}$ & $\begin{array}{l}\text { AF346766 } \\
\text { AF374356 } \\
\text { AF346767 } \\
\text { AF346764 } \\
\text { AF374362 } \\
\text { AF346768 } \\
\text { AF346769 } \\
\text { AF346771 } \\
\text { AF374363 } \\
\text { AF346765 }\end{array}$ \\
\hline
\end{tabular}

${ }^{\text {a }}$ Provinces in South Africa: EC = Eastern Cape, GP = Gauteng Province, KZN = KwaZulu Natal, MP = Mpumalanga Province, S Cape = Southern Cape, part of the Western Cape Province.

b GenBank accession numbers. 
sets showed a clear distinction between $G$. citricarpa, with a PCR amplicon of approximately $580 \mathrm{bp}$, and $G$. mangiferae, approximately 430 bp (Fig. 1A and B). PCR results obtained for previously sequenced isolates confirmed their identities based on sequence data with no exceptions. Isolates described in Table 2 also gave similar results, with all isolates from other hosts or asymptomatic material producing a band of approximately $430 \mathrm{bp}$, indicating that these isolates were $G$. mangiferae (Fig. 1A and B). All symptoms, regardless of the type, shape, and size on fruit produced positive results for Guignardia. Isolates from typical CBS symptoms all produced a PCR amplicon of approximately $580 \mathrm{bp}$, indicating that they were $G$. citricarpa. The only exceptions were an isolate from a red margin hard spot lesion on Marsh grapefruit, which were shown to be $G$. mangiferae. The ex-holotype culture of G. citricarpa (CBS111.20) tested positive for $G$. citricarpa.

Isolates of unknown identity were tested and PCR results compared to the source from which they were isolated. In all cases, the isolates were G. citricarpa (Figs. 2 and 3), which was consistent with the cultural morphology and growth rate characteristics for this organism. In all assays, no reactions were obtained from the $C$. gloeosporioides and water controls. The same results were obtained for all five replicates (data not shown).
The BLAST analysis done using the primer specific for $G$. citricarpa (CITRIC1) showed several matches, all of which were G. citricarpa sequences depos-

ited by Meyer et al. (28). The only other matches obtained were those of G. citricarpa sequences deposited by Baayen et al. (6). There were no other matches for

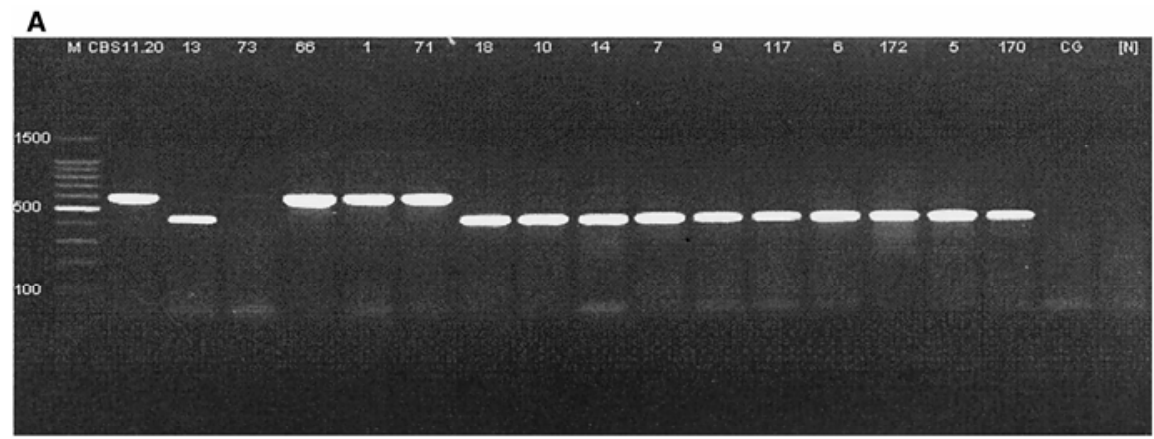

B

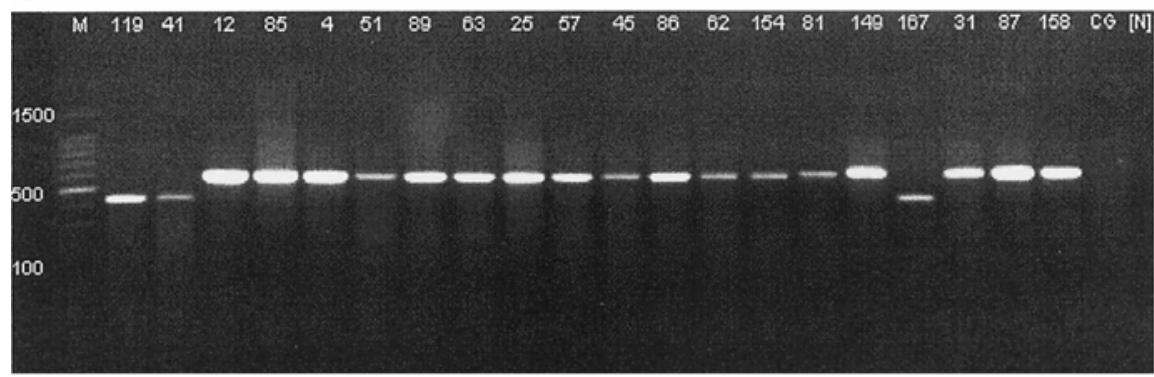

Fig. 1. DNA amplification products from primers ITS4, CITRIC1, and CAMEL2. A, Predominantly Guignardia mangiferae isolates, with G. citricarpa isolates included for comparative purposes. B, Predominantly G. citricarpa isolates, with G. mangiferae isolates included for comparative purposes. CG in both cases denotes a Colletotrichum gloeosporioides control, and $[\mathrm{N}]$ is a negative water control. The first lane in both cases is a 100-bp ladder.

Table 2. Isolates of unknown identity retrieved from fruit lesions or freeze-dried mycelium, and/or direct potato dextrose agar (PDA) isolations, using the DNeasy Plant Mini Kit, and identified with ITS4, CITRIC1, and CAMEL2 primers

\begin{tabular}{|c|c|c|c|c|c|}
\hline Isolate code & Origin $^{a}$ & Host cultivar & Lesion type & DNA isolation source & PCR result \\
\hline GC1 & Sandvlei, NW & Citrus sinensis cv. Valencia & Hard spot & Freeze-dried mycelium & $\mathrm{GC}^{\mathrm{b}}$ \\
\hline GC12 & Letaba, MP & C. sinensis $\mathrm{cv}$. Valencia & Hard spot & Freeze-dried mycelium & GC \\
\hline GC13 & Sao Paolo, Brazil & C. sinensis cv. Valencia & Hard spot & Freeze-dried mycelium & $\mathrm{GC}$ \\
\hline GC71 & Croc Valley, MP & C. sinensis cv. Valencia & False melanose & PDA culture & $\mathrm{GC}$ \\
\hline GC85 & Nelspruit, MP & C. sinensis cv. Valencia & Hard spot & PDA culture & $\mathrm{GC}$ \\
\hline GC86 & Nelspruit, MP & C. sinensis cv. Valencia & Virulent spot & PDA culture & $\mathrm{GC}$ \\
\hline GC89 & Nelspruit, MP & C. sinensis cv. Valencia & Hard spot & PDA culture & GC \\
\hline GC158 & South Zimbabwe & C. sinensis cv. Valencia & Hard spot & PDA culture & GC \\
\hline TR02/06/01.1 & Marble Hall, MP & C. sinensis cv. Valencia & False melanose & Fruit lesion + PDA culture & GC \\
\hline TR02/06/01.3 & Marble Hall, MP & C. sinensis cv. Valencia & Red margin hard spot & Fruit lesion + PDA culture & GC \\
\hline TR02/06/01.4 & Marble Hall, MP & C. sinensis cv. Valencia & Freckled spot & Fruit lesion + PDA culture & GC \\
\hline TR03/09/03.1 & Unknown & C. sinensis cv. Valencia & Hard spot & Fruit lesion + PDA culture & GC \\
\hline CV6 & Croc Valley, MP & C. sinensis $\mathrm{cv}$. Midnight & Virulent spot & Fruit lesion + PDA culture & GC \\
\hline CV25 & Croc Valley, MP & C. sinensis cv. Navel & Virulent spot & Fruit lesion + PDA culture & GC \\
\hline CV29 & Croc Valley, MP & C. sinensis $\mathrm{cv}$. Navel & False melanose & Fruit lesion + PDA culture & $\mathrm{GC}$ \\
\hline GC57 & Croc Valley, MP & C. limon cv. Eureka & Hard spot & PDA culture & $\mathrm{GC}$ \\
\hline GC73 & Karino, MP & C. limon cv. Eureka & Hard spot & PDA culture & $\mathrm{GC}$ \\
\hline GC170 & Sondagsriver Valley, SCape & C. limon cv. Eureka & No lesion & PDA culture & GC \\
\hline TR03/03/03.1 & Unknown & C. limon cv. Eureka & No lesion & Fruit & GC \\
\hline TR03/03/03.2 & Unknown & C. limon cv. Eureka & Small hard spot lesions & Fruit lesion + PDA culture & GC \\
\hline TR03/03/03.3 & Unknown & C. limon cv. Eureka & Small hard spot lesions & Fruit lesion + PDA culture & GC \\
\hline TR03/03/03.4 & Unknown & C. limon cv. Eureka & Big hard spot lesions & Fruit lesion + PDA culture & $\mathrm{GC}$ \\
\hline C9.1 & Chiredzi, Zimbabwe & C. limon cv. Eureka & False melanose & PDA culture & GC \\
\hline C10.1 & Chiredzi, Zimbabwe & C. limon cv. Eureka & $\mathrm{FM}$ and $\mathrm{VIR}^{\mathrm{c}}$ & Fruit lesion + PDA culture & $\mathrm{GC}$ \\
\hline K9 & Karino, MP & C. limon cv. Eureka & FM and VIR & Fruit lesion & GC \\
\hline GC81 & Croc Valley, MP & C. paradisi $\mathrm{cv}$. Marsh & Hard spot & PDA culture & GC \\
\hline GC167 & K. Naidoo, KZN & C. paradisi cv. Marsh & Hard spot & PDA culture & GM \\
\hline GC7 & Tzaneen, MP & Mangifera indica & No symptoms & Freeze-dried mycelium & GM \\
\hline GC9 & Tzaneen, MP & M. indica & No symptoms & PDA culture & GM \\
\hline
\end{tabular}

a Provinces in South Africa: KZN = Kwazulu Natal, MP = Mpumalanga Province, NW = North Western Province, SCape = Southern Cape, part of the Western Cape Province.

${ }^{\mathrm{b}} \mathrm{GC}=$ Guignardia citricarpa, $\mathrm{GM}=$ Guignardia mangiferae.

c $\mathrm{FM}=$ false melanose, $\mathrm{VIR}=$ virulent spot. 
this sequence. The analysis done with the primer specific for $G$. mangiferae (CAMEL2) showed several matches. These included those deposited by Meyer et al. (28), designated Guignardia sp. (endophyte), and those deposited by Baayen et al. (6), which were the newly described $G$. mangiferae. Other matches included a Phyllosticta sp. MSR1 (32) and a Guignardia endophyllicola (31). There were no other matches for this sequence.

Evaluation of DNeasy Plant Mini Kit. A high-concentration pure DNA of PCR quality (without any RNA or cellular contaminants) was successfully and consistently extracted from cultures, freeze-dried mycelium, and fruit lesions. A very small amount of lesion tissue, regardless of the symptom, is required to produce a sufficient DNA concentration for PCR detec- tion. The extraction process is completed in approximately 2 to $3 \mathrm{~h}$.

\section{DISCUSSION}

A set of two primers was designed to distinguish between $G$. citricarpa and $G$. mangiferae in conjunction with the ITS4 primer in a PCR test. PCR-based techniques for diagnosis and differentiation of pathogens of quarantine importance has proved to be very useful, as in the case of Xanthomonas axonopodis pv. citri, the causal agent of bacterial canker of citrus (11). Furthermore, the application of the information contained within the ITS region of rDNA for diagnostic purposes is well documented $(16,25,35,39,41)$. The positive PCR identification of all previously sequenced isolates (28) proved that this assay is robust and reliable, since the PCR results obtained using this primer set were in ac-

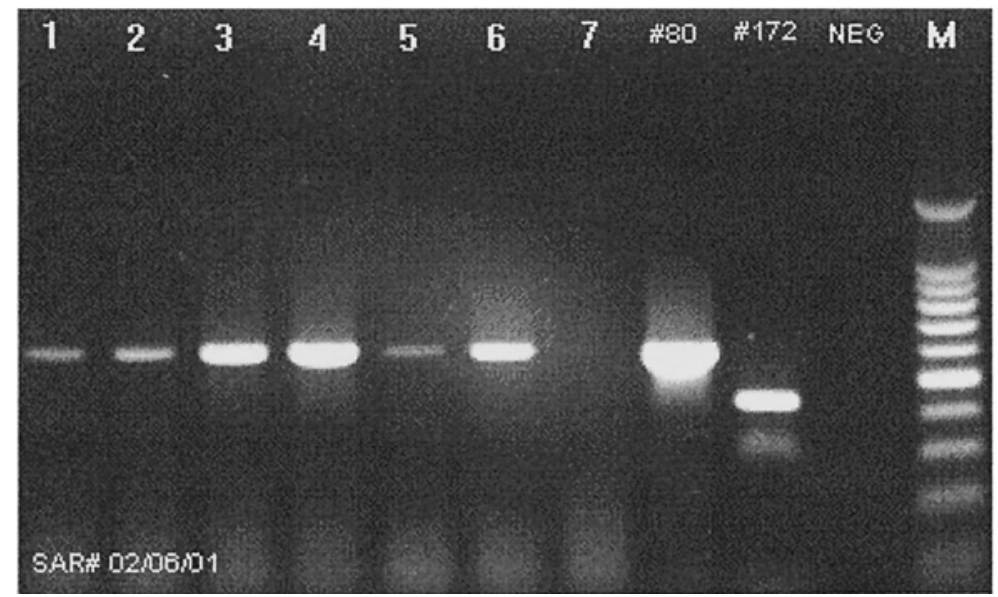

$500 \mathrm{bp}$

$100 \mathrm{bp}$

Fig. 2. Use of species-specific primers on direct fruit lesion DNA extracts of unknown identity. Samples on the gel are direct DNA extracts of: lane 1, false melanose lesion (TR02/06/01.1); lane 2, hard spot lesion (TR03/09/03.1); lane 3, virulent spot (CV6); lane 4, freckled spot (TR02/06/01.4); lane 5, hard spot lesion (TR03/03/03.4); lane 6, virulent spot (C10.1); lane 7, false melanose (C10.1). Isolates $\# 80$ and \#172 serve as Guignardia citricarpa and G. mangiferae controls; (NEG) denotes a negative water control; $\mathrm{M}$ denotes a 100-bp ladder.

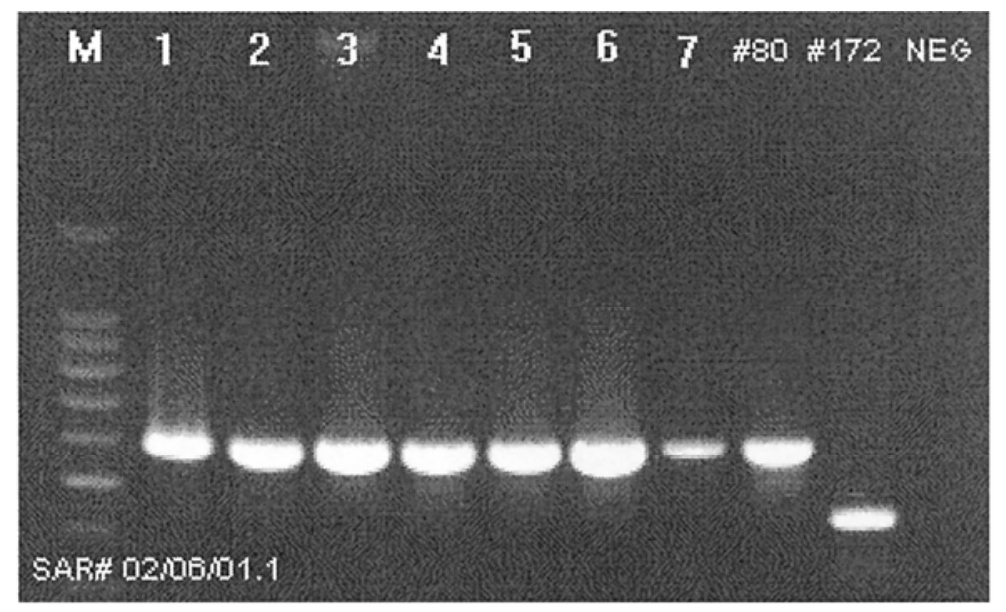

Fig. 3. Use of species-specific primers on DNA from cultures ex fruit lesions of unknown identity. Samples on the gel are as follows: lane 1, false melanose isolate (TR02/06/01.1); lane 2, hard spot isolate (TR03/09/03.1); lane 3, virulent spot isolate (CV6); lane 4, freckled spot isolate (TR02/06/01.4); lane 5, hard spot isolate (TR03/03/03.4); lane 6, virulent spot isolate (C10.1); lane 7, false melanose isolate (C10.1). Isolates \#80 and \#172 serve as Guignardia citricarpa and G. mangiferae controls; (NEG) denotes a negative water control; M denotes a 100-bp ladder. cordance with the described sequence data. This was further confirmed by the positive identification of the ex-holotype culture (CBS 111.20) of G. citricarpa.

Currently, CBS is diagnosed from classical hard spot symptoms with Phyllosticta citricarpa pycnidia within these lesions. This type of diagnosis is complicated by the presence of less distinctive symptoms such as false melanose and freckle spot, which are the most common type of intercepted symptoms (6). Identification was primarily done by culturing and visual identification with a very low efficacy rate. It has also been shown that despite efforts to exclude contaminants, up to $60 \%$ of isolates are identified as $C$. gloeosporioides and only $27 \%$ as Guignardia spp. (15). The presence of contaminants such as C. gloeosporioides and the long time required for sufficient growth of the fungus resulted in the search for another more efficient technique.

When various symptoms and lesions on fruit were analyzed in this study using the DNeasy kit and the designed primers, Guignardia spp. were consistently positively identified, also with the use of single lesions. This was furthermore confirmed when corresponding PDA cultures and direct DNA fruit lesion isolations (originating from the same lesion) tested positive for G. citricarpa. The consistency of positive identification found in this study proves the sensitivity of these primers in detecting the presence of Guignardia in plant tissue. This method reduces the required testing time significantly. This is one of the most important benefits resulting from the implementation of molecular based techniques coupled with increased sensitivity (24).

Two of the isolates obtained from symptomatic citrus material were identified as $G$. mangiferae (Table 1 and 2). This could be ascribed either to a multiple infection of both G. citricarpa and G. mangiferae within those particular lesions or to the formation of lesions due to infection by $G$. mangiferae. Baayen et al. (6) found that upon isolation, particularly from minute spots, $G$. mangiferae could readily be isolated.

Most importantly, it has been shown in our study that these primers do not react with any fungal genera. This was confirmed by PCR and BLAST searches. Some of the matches obtained in the BLAST search for CAMEL2 were an ascomycetous fungal endophyte MS3 ISI109 (21) and a $G$. endophyllicola (31). Since these sequences were published before the designation of $G$. mangiferae (6), it is highly probable that these sequences were from isolates currently known as $G$. mangiferae.

Extracting good quality DNA directly from any fruit lesion, using the DNeasy Plant Mini DNA extraction kit, makes routine diagnosis of $G$. citricarpa in export consignments more cost and time effective. 
This is critical, particularly in the case of South African fruit exports, where delays can result in missing the reefer's scheduled departure date with subsequent rescheduling and divergence to alternative markets. It is now possible to extract DNA directly from the citrus fruit and to perform the PCR successfully with very specific and robust Guignardia primers all within a day. The verification of questionable consignments can therefore be streamlined by rapid and accurate diagnosis of citrus fruit spots.

The EU and USA consider the pathogenic strain, G. citricarpa, to be a serious phytosanitary risk and have therefore imposed regulations on the import of fruit consignments in terms of the presence of CBS on fruit. However, these restrictions are limited to $G$. citricarpa and exclude $G$. mangiferae $(4,6)$. The study by Baayen et al. (6) confirmed that G. mangiferae has a very wide host range and occurs worldwide. They therefore concluded that the exclusion of $G$. mangiferae from quarantine legislation was justified. The primer sets and test method described in this paper provide an effective, rapid, accurate, and validated protocol for one-day analysis of fruit in questionable rejected export consignments.

\section{ACKNOWLEDGMENTS}

This work was supported in part by a grant from the Technology and Human Resources for Industry Programme (THRIP); a partnership programme funded by the Department of Trade and Industry (DTI) and managed by the National Research Foundation (NRF). We thank Prof. L. H. Nel, Department of Microbiology and Plant Pathology, University of Pretoria for help with developing the CITRIC1 and CAMEL2 primers.

\section{LITERATURE CITED}

1. Altschul, S. F., Gish, W., Miller, W., Meyers, E. W., and Lipman, D. J. 1990. Basic local alignment search tool. J. Mol. Biol. 215:403-410.

2. Anonymous. 1998. Commission Decision of 8 January 1998 recognising certain third countries and certain areas of third countries as being free of Xanthomonas campestris (all strains pathogenic to citrus), Cercospora angolensis Carv. et Mendes and Guignardia citricarpa Kiely (all strains pathogenic to citrus) The European Union Online.

3. Anonymous. 2000. Special requirements for import of plants, plant products and other objects originating in third countries. O. J. Eur. Comm. 169:44-45.

4. Anonymous. 2003. Diagnostic protocols for regulated pests: Guignardia citricarpa. EPPO Bull. 33:271-280.

5. Araujo, W. L., Maccheroni, W., Jr., Aguilar, V. C. I., Barrosso, P. A. V., Saridakis, H. O., and Azevedo, J. L. 2001. Variability and interactions between endophytic bacteria and fungi isolated from leaf tissues of citrus rootstocks. Can. J. Microbiol. 47:229-236.

6. Baayen, R. P., Bonants, P. J. M., Verkley, G., Carroll, G. C., van der Aa, H. A., de Weerdt, M., van Brouwershaven, I. R., Schutte, G. C., Maccheroni, W., Jr., De Blanco, C. G., and Azevedo, J. L. 2002. Nonpathogenic isolates of the citrus black spot fungus, Guignardia citricarpa, identified as a cosmopolitan endophyte of woody plants, G. mangiferae (Phyllosticta capitalensis). Phytopathology 92:464-477.

7. Bach, H. J., Tomanova, J., Schloter, M., and
Munch, J. C. 2002. Enumeration of total bacteria and bacteria with genes for proteolytic activity in pure cultures and in environmental samples by quantitative PCR mediated amplification. J. Microbiol. Methods 49:235-245.

8. Baigent, H. 1996. The role of testing and laboratory accreditation in international trade. International Laboratory Accreditation Cooperation (ILAC). Published online.

9. Bonants, P. J. M., Carroll, G. C., De Weerdt, M., Van Brouwershaven, I. R., and Baayen, R. P. 2003. Development and validation of a fast PCR-based detection method for pathogenic isolates of the citrus black spot fungus, Guignardia citricarpa. Eur. J. Plant Pathol. 109:503-513.

10. Brodrick, H. T. 1969. Physiological studies with Guignardia citricarpa Kiely. D.Sc. thesis. Department of Microbiology and Plant Pathology, University of Pretoria, South Africa.

11. Cubero, J., and Graham, J. H. 2002. Genetic relationship among worldwide strains of Xanthomonas causing canker in citrus species and design of new primers for their identification by PCR. Appl. Environ. Microbiol. 68:1257-1264.

12. Dauch, A. L., Watson, A. K., and Jabaji-Hare, S. H. 2003. Detection of the biocontrol agent Colletotrichum coccodes (183088) from the target weed velvetleaf and from soil by strainspecific PCR markers. J. Microbiol. Methods 55:51-64.

13. FAO. 2000. Citrus fruit fresh and processed: Annual statistics. Food and Agriculture organization of the United Nations. Published online.

14. Fogliato, G. M., Canton, N. V., and Ploper, L. D. 2000. Laboratory analysis for certification of citric fruit from North East Argentina (NOA) destined for the European Union (EU). Advanced Agroindustrial 21:4-7.

15. Glienke-Blanco, C., Aguilar-Vildoso, C. I., Veira, M. L. C., Barrosso, P. A. G., and Azevedo, J. L. 2002. Genetic variability in the endophytic fungus Guignardia citricarpa isolated from citrus plants. Genet. Mol. Biol. 25:251-255.

16. Jacobs, K. A., and Rehner, S. A. 1998. Comparison of cultural and morphological characters and ITS sequences in anamorphs of Botryosphaeria and related taxa. Mycologia 90:601-610.

17. Kiely, T. B. 1948. Preliminary studies on Guignardia citricarpa, n.sp.: The ascigerous stage of Phoma citricarpa McAlp. and its relation to black spot of citrus. P. Linn. Soc. N.S.W. 73:249-292.

18. Kotzé, J. M. 1963. Studies on the black spot disease of citrus caused by Guignardia citricarpa Kiely, with particular reference to its epiphytology and control at Letaba. D.Sc. (Agric.) thesis. University of Pretoria, South Africa.

19. Kotzé, J. M. 1981. Epidemiology and control of citrus black spot in South Africa. Plant Dis. 65:945-950.

20. Kotzé, J. M. 1996. History and epidemiology of citrus black spot in South Africa. Proc. Int. Soc. Citric. 2:1296-1299.

21. Lacap, D. C., Liew, E. C. Y., and Hyde, K. D. 2001. An evaluation of the fungal 'morphotype' concept based on ribosomal DNA sequences. NCBI, National Library of Medicine, PubMed. Published online.

22. Landeweert, R., Veenman, C., Kuyper, T. W., Fritze, H., Wernars, K., and Smit, E. 2003. Quantification of ectomycorrhizal mycelium in soil by real-time PCR compared to conventional quantification techniques. FEMS Microbiol. Ecol. 45:283-292.

23. Maniatis, T., Fritsch, E. F., and Sambrook, J. 1982. Molecular Cloning: A Laboratory Manual. Cold Spring Harbor Laboratory, Cold Spring Harbor, NY
24. Martin, R. R., James, D., and Levesque, C. A. 2000. Impacts of molecular diagnostic technologies on plant disease management. Annu. Rev. Phytopathol. 38:207-239.

25. Martinez-Culebras, P. V., Barrio, E., Garcia, M. D., and Querol, A. 2000. Identification of the Colletotrichum species responsible for anthracnose of strawberry based on the internal transcribed spacers of the ribosomal region. FEMS Microbiol. Lett. 189:97-101.

26. McOnie, K. C. 1964. The latent occurrence in citrus and other hosts of a Guignardia easily confused with $G$. citricarpa, the citrus black spot pathogen. Phytopathology 54:40-43.

27. McOnie, K. C. 1965. Studies on the host range of the black spot fungus. S. Afr. Citrus J. 378:5-9.

28. Meyer, L., Slippers, B., Korsten, L., Kotzé, J. M., and Wingfield, M. J. 2001. Two distinct Guignardia species associated with citrus in South Africa. S. Afr. J. Sci. 97:191-194.

29. Michelmore, R. W., and Hulbert, S. H. 1987. Molecular markers for genetic analysis of phytopathogenic fungi. Annu. Rev. Phytopathol. 25:383-404.

30. Mitchell, J. I., Roberts, P. J., and Moss, S. T. 1995. Sequence or structure? A short review on the application of nucleic acid sequence information to fungal taxonomy. Mycologist 9:67-75.

31. Okane, I., Nakagiri, A., and Ito, T. 2001. Identity of Guignardia sp. inhabiting ericaceous plants. Can. J. Bot. 79:101-109.

32. Pandey, A. K., Reddy, M. S., and Suryanarayanan, T. S. 2003. ITS-RFLP and ITS sequence analysis of a foliar endophytic Phyllosticta from different tropical trees. Mycol. Res. 107:439-444.

33. Pennanen, T., Paavolainen, L., and Hantula, J. 2001. Rapid PCR-based method for the direct analysis of fungal communities in complex environmental samples. Soil Biol. Biochem. 33:697-699.

34. Raeder, U., and Broda, P. 1985. Rapid preparation of DNA from filamentous fungi. Lett. Appl. Microbiol. 1:17-20.

35. Rehner, S. A., and Uecker, F. A. 1994. Sequence variation in nuclear ribosomal DNA spacers ITS-1 and ITS-2 in Phomopsis. Can. J. Bot. 72:1666-1674

36. Salazar, O., Julian, M. C., and Rubio, V. 2000. Primers based on specific rDNA-ITS sequences for PCR detection of Rhizoctonia solani, $R$. solani AG2 subgroups and ecological types, and binucleate Rhizoctonia. Mycol. Res. 104:281-285.

37. Sutton, B. C., and Waterson, J. M. 1966. CMI Descriptions of Pathogenic Fungi and Bacteria. Guignardia citricarpa. No. 85. Commonwealth Mycological Institute, Kew, Surrey, England.

38. Van Der Aa, H. A. 1973. Studies in Phyllosticta 1. Stud. Mycol. 5:1-110.

39. Waalwijk, C. J., De Koning, R. A., Baayen, R. P., and Gams, W. 1996. Discordant groupings of Fusarium spp. from sections Elegans, Liseola and Dlamina based on ribosomal ITS 1 and ITS 2 sequences. Mycologia 88:361-368.

40. Wager, V. A. 1952. The black spot disease of citrus in South Africa. Sci. Bull. Dep. Agric. S. Afr. 303:1-52

41. Weiland, J. J., and Sundsbak, J. L. 2000. Differentiation and detection of sugar beet fungal pathogens using PCR amplification of actin coding sequences and the ITS region of the rRNA gene. Plant Dis. 84:475-482.

42. White, T. J., Bruns, T., Lee, S., and Taylor, J. 1990. Amplification and direct sequencing of fungal rDNA genes for phylogenetics. Pages 315-322 in: PCR Protocols: A Guide to Methods and Applications. M. A. Innis, D. H. Gelfand, J. J. Sninsky, and T. J. White, eds. Academic Press, San Diego, CA. 